This document is the accepted manuscript version of the following article:

Limberger, R., Birte1, J., Peter, H., Catalán, N., da Silva Farias, D., Best, R. J., ... Matthews, B. (2019). Predator-induced changes in dissolved organic carbon dynamics. 0ikos, 128(3), 430-440. https://doi .org/10.1111/oik.05673

\title{
1 Predator-induced changes in dissolved organic carbon dynamics
}

2

3 Romana Limberger ${ }^{1,2}$, Julia Birtel ${ }^{1}$, Hannes Peter ${ }^{3,4}$, Núria Catalán ${ }^{5}$, Daniel da Silva Farias ${ }^{6}$,

$4 \quad$ Rebecca J. Best ${ }^{7}$, Jakob Brodersen ${ }^{8}$, Helmut Bürgmann ${ }^{9}$, Blake Matthews ${ }^{1,10}$

61 Eawag, Department of Aquatic Ecology, Kastanienbaum, Switzerland

$7 \quad 2$ Research Department for Limnology, University of Innsbruck, Mondsee, Austria

83 Stream Biofilm and Ecosystem Research Laboratory, Ecole Polytechnique Fédérale de

9 Lausanne, Lausanne, Switzerland

4 Lake and Glacier Ecology Research Group, Institute of Ecology, University of Innsbruck,

Innsbruck, Austria

5 ICRA, Catalan Institute for Water Research, Girona, Spain

6 UNIRIO, Núcleo de Estudos Limnológicos, Rio de Janeiro, Brazil

7 School of Earth Sciences and Environmental Sustainability, Northern Arizona University,

USA

8 Eawag, Department of Fish Ecology and Evolution, Kastanienbaum, Switzerland

9 Eawag, Department of Surface Waters, Kastanienbaum, Switzerland

${ }^{10}$ Author of correspondence: Blake Matthews, Eawag, Seestrasse 79, 6047 Kastanienbaum,

Switzerland. e-mail: blake.matthews@eawag.ch

Orcid IDs:

Romana Limberger: 0000-0002-9421-7520

Blake Matthews: 0000-0001-9089-704X 
27 E-mail: romana.limberger@uibk.ac.at, julia.birtel@gmail.com, hannes.peter@epfl.ch,

28 ncatalangarcia@gmail.com, fariassd@gmail.com, rebecca.best@nau.edu,

29 jakob.brodersen@eawag.ch, helmut.buergmann@eawag.ch, blake.matthews@eawag.ch 


\section{Predator-induced changes in dissolved organic carbon dynamics}

2

3

4

5

\section{Abstract}

The fate of dissolved organic carbon (DOC) is strongly determined by its availability to microbial degradation. Organisms at upper trophic levels could influence the bioavailability of DOC via cascading effects on primary producers and bacteria. Here we experimentally tested whether the presence of fish in aquatic food webs can indirectly affect the composition of the DOC pool. We found that fish had strong positive effects on phytoplankton biomass that affected the dynamics of DOC bioavailability. Fish also increased bacterial abundance, altered the community composition and diversity of bacteria, and temporarily increased DOC compounds originating from microbial reprocessing of organic matter. Overall, we propose that organisms at upper trophic levels can influence biogeochemical processes associated with carbon sequestration by influencing the substrate (bioavailable DOC) and the key players (bacteria) of the microbial carbon pump. This is a novel mechanism whereby the loss of predators from global ecosystems could alter carbon cycling.

Key words: bacteria, carbon cycle, DOC, experiment, fish, food web, mesocosms, phytoplankton, trophic cascade 


\section{Introduction}

Animals play an important role in carbon cycling by influencing major pathways governing the fixation, transfer, and sequestration of carbon (Atwood et al. 2013, Devlin et al. 2015, Schindler et al. 1997, Schmitz et al. 2014). In aquatic systems, trophic pathways, such as the algae-based food chain and the microbial loop (Azam et al. 1983), transfer the carbon fixed by primary producers to higher trophic levels (Fig. 1). These trophic pathways can influence carbon sequestration, either via export of particulate organic carbon to the sediment (biological carbon pump; Ducklow et al. 2001, Eppley and Peterson 1979) or via microbial degradation of bioavailable to persistent DOC (microbial carbon pump; Jiao et al. 2010). While algae and bacteria are key drivers of carbon sequestration, the role of organisms at higher trophic levels is less explored despite their potentially strong effects on carbon fixation and fluxes (Atwood et al. 2013, Devlin et al. 2015, Schindler et al. 1997).

Predators in aquatic systems are known for their profound effects on biodiversity and biomass structure (Carpenter et al. 2001, Carpenter et al. 1985, Stibor et al. 2004), but their effects on carbon sequestration pathways in general, and on the microbial carbon pump in particular, are poorly characterized. Previous studies showed that fish can stimulate the biological carbon pump by increasing primary production (Atwood et al. 2013, Schindler et al. 1997) and sedimentation rates (Flanagan et al. 2006), resulting in reduced emission of $\mathrm{CO}_{2}$ from freshwater ecosystems (Atwood et al. 2013, Flanagan et al. 2006, Schindler et al. 1997). Fish can also influence the key components of the microbial carbon pump: fish can have cascading effects on the abundance and composition of bacterial communities (Saarenheimo et al. 2016, Shurin et al. 2012, Sullam et al. 2017), and on the algal contribution to DOC (Harmon et al. 2009). Collectively, these previous studies suggest that trophic effects of fish can extend beyond their impacts on biomass and biodiversity, so as to influence carbon cycling (Schmitz et al. 2014). 
Dissolved organic carbon is central to carbon cycling in aquatic systems, and its wide

variation in reactivity strongly influences the remineralization and storage of carbon (Findlay and Sinsabaugh 2003). The reactivity continuum of DOC is determined by the complexity of its constituent compounds (Benner 2003, Benner and Amon 2015, Findlay and Sinsabaugh 2003, Mostovaya et al. 2016) and thus by the biomass structure and composition of the bacterial and algal communities that produce and degrade DOC (Benner 2003, Giroldo and Vieira 2005, Logue et al. 2016). Algae produce DOC that contains a larger fraction of bioavailable compounds than allochthonous, terrestrially-derived DOC (Amon and Benner 1996). During microbial degradation, DOC becomes progressively less reactive due to changes in molecular composition and average molecular size reductions (Amon and Benner 1994, Amon and Benner 1996, Benner and Amon 2015). In addition to these biomass effects, species-specific differences in the production, uptake, and degradation of different DOC compounds (Amaral et al. 2016, Giroldo and Vieira 2005, Logue et al. 2016, Simek et al. 2011) can also affect DOC reactivity. We propose that fish could influence the reactivity continuum of the DOC pool via their indirect effects on the biomass, diversity, and composition of algal and bacterial communities. As such, anthropogenic impacts on predators (Duffy 2003, Estes et al. 2011) might have important but poorly understood consequences for carbon cycling.

Using experimental freshwater ecosystems, we tested if the effects of fish would propagate downward through multiple trophic levels in the aquatic food web and alter the DOC pool. In 40 tanks each filled with $1000 \mathrm{~L}$ of lake water, we manipulated the presence of fish, the three-spined stickleback, and quantified the effect of fish on the biomass and composition of zooplankton (i.e. crustaceans and rotifers), phytoplankton, and bacteria, as well as the concentration and composition of DOC. We predicted that a fish-mediated trophic cascade would reduce zooplankton biomass, and thereby increase the biomass of phytoplankton and potentially of bacteria. We expected that the indirect positive effect of fish 
on phytoplankton would increase the proportion of phytoplankton-derived DOC, and thus, of bioavailable compounds in the DOC pool. This in turn, might promote higher abundances of bacteria and alter bacterial community composition, thus influencing DOC composition during DOC processing. We here provide some of the first experimental evidence that cascading trophic interactions can influence DOC dynamics and propose this as a novel mechanism whereby organisms at upper trophic levels can affect carbon cycling.

\section{Material and methods}

\section{Experiment}

In a mesocosm experiment, we manipulated the presence of living fish, Gasterosteus aculeatus (three-spined stickleback). Stickleback are both plankti- and benthivorous fish and feed primarily on macrozooplankton (e.g. Copepoda and Cladocera) and on benthic macroinvertebrates (e.g. chironomids). We constructed experimental aquatic ecosystems using 40 outdoor tanks of $1000 \mathrm{~L}$ (dimensions: 1 x 1 x $1 \mathrm{~m}$ ). After covering the bottom of the tanks with a layer of gravel, sand and sediment, the tanks were filled with water of Lake Luzern and additionally inoculated with plankton (i.e. bacteria, phyto-, and zooplankton) from lakes Alpnach and Rot. At the start of the experiment (May 7th, 2012), 20 tanks were each stocked with six female stickleback (average length: $4.4 \mathrm{~cm}$; average weight: $1.4 \mathrm{~g}$ ). Each tank received stickleback that were collected from two sites, three stickleback from the shores of Lake Geneva (46 $31^{\prime} 00.0^{\prime \prime} \mathrm{N} ; 6^{\circ} 34^{\prime} 38.0^{\prime \prime} \mathrm{E}$ ) and three from a river flowing into Lake Geneva $\left(46^{\circ} 12^{\prime} 49.5^{\prime \prime} \mathrm{N} ; 7^{\circ} 18^{\prime} 52.3^{\prime \prime} \mathrm{E}\right)$. At the outset of the experiment, we thought these lake and river populations might be ecologically and genetically differentiated (i.e. be ecotypes), and so we decided to use the same number of fish from both populations. Further analyses found no genetic differentiation between these two populations (Marques 2016), and so our fish treatment effectively consists of six stickleback from the Lake Geneva watershed. 
The results presented here are a subset of a larger experiment (Supplementary material Appendix 1 Fig. A1) testing how ecosystem fluxes and patch heterogeneity affect the structure and functioning of metaecosystems, i.e. sets of ecosystems connected by the flux of organisms, matter, and energy (Loreau et al. 2003). For this reason, pairs of fish/fishless tanks received $1 \mathrm{~L}$ input of water from three donor ecosystems in bi-weekly intervals (Supplementary material Appendix 1 Fig. A1; see Limberger et al. (2017) for detailed description of donor ecosystems). Because we wanted to keep the total initial nutrient load of the metaecosystems similar, we added six dead stickleback to each of the fishless tanks. These fish decomposed rapidly over the course of the experiment, and we do not think that they were a substantial pulse of particulate organic carbon to the total carbon budget of the mesocosms. We did not replace fish that died over the course of the experiment in tanks with living fish. Here, in order to focus on the fish contrast, we used pairs of tanks (i.e. tanks connected to the same donor ecosystems) as a random factor in our analyses. This allows us to account for the non-independence of the two tanks that are connected to the same donor ecosystems, and to isolate the effects of living fish on aquatic ecosystems (i.e. using 20 pairs of tanks).

We did not attempt to simulate a particular type of aquatic system (e.g. lake, pond, stream) with our experiment. Rather, the goal of our mesocosm experiment was to extend the concept of the microbial carbon pump by integrating predators, and experimentally testing how (living) organisms at upper trophic levels can influence the composition of the DOC pool.

\section{Biotic parameters}

Over a period of 19 weeks (May $14^{\text {th }}$ to September $17^{\text {th }}, 2012$ ), we quantified phytoplankton biomass and abundances of bacteria in bi-weekly intervals. We measured chlorophyll-a as a proxy for phytoplankton biomass using high performance liquid chromatography (HPLC) after filtering water from the tanks on GF/F filters (Whatman). To 
determine bacterial abundances, we fixed samples with a solution of paraformaldehyde and glutaraldehyde (0.01\% and 0.1\% final concentrations, $\mathrm{pH} 7)$ (Nizzetto et al. 2012) and counted the number of cells in the sample with a BD Accuri ${ }^{\mathrm{TM}} \mathrm{C} 6$ Flowcytometer. At three sampling dates (weeks $7,13,19$ ), we additionally quantified the biomass of periphyton by extracting chlorophyll from plastic strips that had been suspended in the tanks at the start of the experiment. At weeks 3,11, and 19, we measured net ecosystem productivity as the increase in dissolved oxygen in the tanks from dawn till dusk, and respiration as the decline in dissolved oxygen from dusk until dawn.

At the end of the experiment, we also quantified community composition of phyto-, zooplankton (crustaceans and rotifers), and bacteria. To determine phytoplankton community composition, we identified and counted phytoplankton taxa with an inverted microscope after fixing samples of tank water with Lugol's solution. To determine zooplankton community composition, we sampled $10 \mathrm{~L}$ tank water integrated over the entire water column at six randomly chosen locations. Samples were filtered through a net of $30 \mu \mathrm{m}$ mesh size and stored at $-20^{\circ} \mathrm{C}$. Zooplankton (i.e. crustaceans and rotifers) was identified to species level when possible and counted with a dissecting microscope. We also quantified zooplankton biomass by measuring the lengths of all individuals counted and calculating biomass from published length-dry weight relationships (Baumgärtner and Rothhaupt 2003, Bottrell et al. 1976, Culver et al. 1985, Dumont et al. 1975, Ruttner-Kolisko 1977). We determined the composition of the bacterial community using Illumina sequencing of the $16 \mathrm{~S}$ rRNA gene. Tank water was filtered on poly-ethersulfone filters of $0.2 \mu \mathrm{m}$ mesh size (Supor 200 Membrane Disc Filters), and DNA was extracted using enzymatic digestion and extraction with cetyltrimethyl ammonium bromide (CTAB), following a modified protocol of Lliros et al. (2008). We sequenced the V3 region of the 16S rRNA gene and analyzed the sequencing data using QIIME (Kuczynski et al. 2011), as described previously (Birtel et al. 2015). Sequences of similarity $>97 \%$ were clustered to operational taxonomic units (OTUs), and 
sequencing data was rarefied to 300 reads per sample (Birtel et al. 2015). Bacterial diversity was calculated as the number of OTUs averaged over 100 rarefactions to 300 reads.

\section{Dissolved organic carbon}

We measured the concentration of DOC and DOC absorption spectra in bi-weekly intervals. Tank water was filtered through pre-combusted $\mathrm{GF} / \mathrm{F}$ filters ( $4 \mathrm{~h}$ at $450{ }^{\circ} \mathrm{C}$ ), and the acidified filtrate was used to measure the DOC concentration on a Shimadzu TOC-V CPH. DOC absorption spectra were collected on a spectrophotometer (Hitachi U 2000) over the wavelengths of 190 to $800 \mathrm{~nm}$. Absorbance was converted to absorption coefficients following Helms et al. (2008), and slopes fitted to the wavelength intervals of 275-295 nm $\left(\mathrm{S}_{275-295}\right)$ and $350-400 \mathrm{~nm}\left(\mathrm{~S}_{350-400}\right)$ using non-linear regression of the absorption coefficient spectra using the R package $c$ dom (Massicotte and Markager 2016). The resulting slopes were used to calculate the slope ratio (SR) $\left(\mathrm{S}_{275-295} / \mathrm{S}_{350-400}\right)$ (Helms et al. 2008). Because highmolecular weight DOC compounds absorb light at higher wavelengths than low-molecular weight compounds, a higher slope ratio indicates a lower proportion of high-molecular weight DOC.

To further characterize the origin and reactivity of DOC compounds, we collected fluorescence excitation-emission matrices (EEM) at three sampling dates (weeks 1, 9, and 19). EEMs were obtained using a spectrofluorometer (FluoroMax 4, Horiba). An excitation range of $240-450 \mathrm{~nm}$ at $10 \mathrm{~nm}$ increments and an emission range of $300-560 \mathrm{~nm}$ at $2 \mathrm{~nm}$ increments were used. Samples were internally corrected for instrument specific biases $(\mathrm{Sc} / \mathrm{Rc}$ mode was used). The area underneath the water Raman scan was calculated and used to normalize all sample intensities. Spectra were corrected for the inner filter effect using the absorbance-based approach (Kothawala et al. 2013, McKnight et al. 2001). Corrections were applied using the FDOMcorr toolbox for MATLAB (Mathworks, Natick, MA, USA) following Murphy et al. (2010). The freshness or biological index (BIX) was calculated 
according to Huguet et al. (2009) and the humification index (HIX) according to Ohno (2002) (Supplementary material Appendix 1 Table A1).

Parallel Factor Analysis (PARAFAC) was used to identify the main components of the EEMs (Stedmon et al. 2003) using the DrEEM toolbox (Murphy et al. 2013) for MATLAB (Mathworks, Inc., Natick, MA). Scatter peaks and outliers were removed, and each sample normalized to its total fluorescence prior to fitting a PARAFAC model. Five independent components (C1-C5; Supplementary material Appendix 1 Table A1, Fig. A2) were validated by split-half analysis and random initialization with 10 iterations and by visual inspection of the residual fluorescence and of the components' behavior as organic fluorophores as described in Murphy et al. (2013). In order to be able to compare changes in fluorescence intensities minimizing the effect of the TOC concentration, we normalized the abundances of the PARAFAC components by DOC concentration.

We interpreted the components by comparing them with published components previously identified in aquatic systems available in the OpenFluor data base (http://www.openfluor.org; (Murphy et al. 2013)). Components C1 and C3 correspond to humic-like materials, $\mathrm{C} 1$ has been related with humic-like terrestrial materials as lignins (Walker et al. 2009, Yamashita et al. 2010), similar to Coble's peak A (Cawley et al. 2012). C3 is a ubiquitous component, a mixture between humic-like peaks A and C (Coble 1996), typically high molecular weight humic compounds (Amaral et al. 2016) terrestrially or soilderived (Osburn et al. 2016). Both C5 and C4 are often related to compounds originating from microbial re-working and processing of complex organic matter (Shutova et al. 2014, Yamashita et al. 2010), and appear to have humic-like fluorescence (Lambert et al. 2016). However, C4 has additionally been identified as protein-like (C7 in Murphy et al. (2008)), based on its tryptophan-like fluorescence (Murphy et al. 2008). C2 has been identified as protein-like, with tryptophan-like fluorescence (Yamashita et al. 2013), and has been found to 
be derived from algae (Chari et al. 2013, Fellman et al. 2011, Stedmon and Markager 2005) and positively related with bioavailability (Graeber et al. 2012). .

\section{Data analysis}

We used linear mixed effect models to test for effects of fish on biological and DOC parameters at weeks 9 and 19 of the experiment. We treated pairs of fish/fishless tanks as a random effect because each pair was receiving identical inputs from the same donor ecosystems (Supplementary material Appendix 1 Fig. A1). Biomass and abundance data was log-transformed prior to statistical analyses. Time series data was analyzed with linear mixed effect models with week and fish treatment as fixed factors, and pair and tank as random factors to account for non-independence of tanks within pairs and for repeated sampling of tanks, respectively. To compare the magnitude of fish effects on biological and DOC parameters, we estimated effect sizes by calculating log-response ratios (i.e. $\ln ($ fish/no fish)) of z-transformed data. Log-response ratios were calculated for each pair of fish/fishless tanks and then averaged over the 20 comparisons. We tested if fish affected the composition of bacteria, phyto- and zooplankton using partial distance-based redundancy analysis (db-RDA) of Hellinger-transformed abundance data, with fish treatment as constraining variable and pair of tanks as conditional variable. Similarly, we tested if fish affected the DOC composition using db-RDA of the five PARAFAC components. P-values were computed with the function anova.cca (package vegan), using 10,000 random permutations and taking the nonindependence of connected mesocosms into account. For unconstrained multivariate analyses of community and DOC composition, we used principal coordinates analysis (PCoA). All analyses were computed with R version 3.1.3 (R Core Team 2015). Linear mixed effect models were computed with the package lme4 (version 1.1-9), db-RDA and PCoA were computed with the package vegan (version 2.3.0). 


\section{Results}

Effects of living fish on aquatic communities

Our initial manipulation of fish was sustained over the course of the experiment: we recaptured living fish at the end of the experiment from all tanks that had been stocked with living fish (recapture rate: $60.8 \%$ ). The presence of living fish in our experimental ecosystems triggered trophic cascades, relative to the ecosystems that received dead-fish biomass. Living fish (hereafter fish) reduced zooplankton biomass and increased both the biomass of phytoplankton and the abundance of bacteria (Fig. 2a, Supplementary material Appendix 1 Table A2, A3). The positive fish effect on phytoplankton biomass was already apparent after one week and persisted throughout the entire course of the experiment (Fig. 3a), while the positive effect of fish on bacterial abundance occurred from week 9 onwards (Fig. 3b). Fish also influenced net ecosystem productivity, with negative effects observed early in the experiment, but positive effects later in the experiment (Fig. 3c) - a reversal that might reflect contrasting effects of fish on phytoplankton (positive) and periphyton (negative) over the course of the experiment (Fig. 3a and 3d).

Cascading trophic interactions also influenced both the diversity and composition of aquatic communities. At the end of the experiment, fish reduced the diversity (i.e. number of taxa) of zooplankton and bacteria, but had no effect on the diversity of phytoplankton (Fig. 2 b, Supplementary material Appendix 1 Table A2). Fish also changed the community composition of all three groups of organisms (Supplementary material Appendix 1 Table A4, Fig. A3, A4). In particular, fish reduced the biomass of crustaceans $(\mathrm{P}<0.001)$ and increased the biomass of rotifers $(\mathrm{P}<0.001)$. Fish altered the composition of the phytoplankton. For example, fish reduced the abundance of Tetraedron (Chlorophyta; $\mathrm{P}<0.001$ ) and increased the abundance of Cosmarium (Charophyta; $\mathrm{P}<0.001$ ). Among the most abundant classes of bacteria, fish reduced the proportion of Gammaproteobacteria $(\mathrm{P}=0.002)$ and increased the 
proportion of Cytophagia $(\mathrm{P}<0.001)$ and Alphaproteobacteria (albeit marginally significant: $\mathrm{P}=0.056$ ). Betaproteobacteria, the most abundant class, were unaffected by fish because of opposing effects of fish on different families of Betaproteobacteria: fish increased the abundance (i.e. number of reads) of Oxalobacteraceae $(\mathrm{P}=0.016)$, but decreased the abundance of Rhodocyclaceae $(\mathrm{P}<0.001)$ and Comamonadaceae $(\mathrm{P}=0.002)$.

\section{Effects of fish on DOC}

The time series data of DOC concentration and absorption spectra show that effects of fish on primary producers translated into effects on both the accumulation of DOC and on the balance of low- and high-molecular weight compounds (Fig. 3e, f, Supplementary material Appendix 1 Tables A2, A3). Fish initially decreased the accumulation of total DOC (weeks 17; Fig. 3e), but had no effect on total DOC later in the experiment. As an indicator of the molecular weight of DOC, we calculated absorption slope ratios (SR) which are inversely related to the molecular weight of DOC (Helms et al. 2008). Tanks with fish initially had a low proportion of low-molecular weight DOC (lower SR than in fishless tanks in week 3; Fig. 3f), but a high proportion later in the experiment (higher SR in weeks 7-11 and 15; Fig. 3f). Fish also affected the fluorescent properties of the DOC pool, as revealed by analyses of fluorescence excitation-emission matrices (EEMs) (Fig. 4, Supplementary material Appendix 1 Table A2). At week 9 of the experiment, fish had a positive effect on BIX, indicating a higher proportion of freshly produced DOC in tanks with fish, and a negative effect on HIX, indicating a lower proportion of humic substances (Fig. 4, Supplementary material Appendix 1 Table A2). Multivariate analyses of the five PARAFAC components demonstrated clear effects of fish on the DOC composition at week 9, but not at week 19 (Supplementary material Appendix 1 Table A5, Fig. A5). At week 9, fish decreased the relative proportion of DOC component C1 (Supplementary material Appendix 1 Table A2) and increased the absolute concentration of components C2 and C4 (Fig. 4, Supplementary material Appendix 1 
Table A2), indicating less humic-like DOC (C1) and higher concentrations of protein-like, bioavailable compounds $(\mathrm{C} 2)$ and compounds originating from microbial reprocessing of organic matter (C4). At the end of the experiment, fish had no effect on indices of freshness or humification, or on the absolute concentrations of the DOC compounds (Fig. 4,

Supplementary material Appendix 1 Table A2), but did increase the relative proportion of C4, i.e. microbially produced DOC, from 14 to $16 \%$ (Supplementary material Appendix 1 Table A2).

\section{Discussion}

Our experiment shows that living fish (hereafter fish) can influence not only the structure of aquatic communities, but also the composition of the DOC pool. We found that fish decreased the biomass of zooplankton, increased the biomass of phytoplankton and the abundance of bacteria, and altered community composition of all three groups of organisms. When fish had the strongest positive effects on phytoplankton biomass (i.e. midway through the experiment), we saw clear increases in the proportion of bioavailable, low-molecular weight DOC derived from algae (PARAFAC component $\mathrm{C} 2$, slope ratio, freshness index). We also observed fish-induced increases in DOC compounds originating from microbial reprocessing of organic matter (PARAFAC component $\mathrm{C} 4$ ), concurrent with positive effects of fish on bacterial abundance. Interestingly, we found no effect of fish on DOC composition at the end of the experiment. The fish-mediated changes in the DOC pool imply that organisms at upper trophic levels can influence the fate of organic carbon by stimulating both the production and degradation of DOC.

The effects of fish on aquatic communities in general, and on phytoplankton in particular could explain fish-induced changes in the pool of dissolved organic carbon. Both DOC absorption spectra and DOC fluorescence properties suggest that the positive effect of fish on phytoplankton biomass translated into a positive effect on bioavailable DOC. Alternatively, 
fish could have directly influenced the DOC pool via excretion. However, the fish-mediated increase in PARAFAC component $\mathrm{C} 2$, which has been found previously as related to phytoplankton (Chari et al. 2013, Fellman et al. 2011, Stedmon and Markager 2005), suggests that effects of fish on bioavailable DOC were primarily indirect by stimulating phytoplankton biomass. Two mechanisms could have caused this positive effect of fish on phytoplankton: reduced grazing pressure because of fish predation on zooplankton (Carpenter et al. 2001, Carpenter et al. 1985, Jakobsen et al. 2004, Shurin et al. 2012), or increased nutrient concentrations because of fish excretion of nitrogen and phosphorus (Vanni et al. 2006, Vanni and Layne 1997). We cannot discern between these two mechanisms, but the negative effect of fish on zooplankton biomass (Fig. 2a) suggests that a trophic cascade was at least partly responsible for the fish-mediated increase in phytoplankton biomass, and thus in bioavailable DOC.

Our experiment also revealed a fish-induced increase in microbially-reprocessed DOC, potentially linked with the positive effect of fish on bacterial abundance, and with the fishmediated changes in bacterial community composition. The effects of fish on the bacterial community could reflect changes in the grazing pressure of macrozooplankton (Pace et al. 1990) or protistan bacterivores (i.e. ciliates and flagellates) (Jürgens et al. 1999, Pernthaler 2005, Simek et al. 2014, Zöllner et al. 2009, Zöllner et al. 2003), or changes in the amount and composition of DOC released from algae and zooplankton (Lampert 1978, Simek et al. 2011, Simek et al. 2014). For example, both classes that responded positively to fish predation, Cytophagia and Alphaproteobacteria, have members than can form filaments or aggregates that reduce grazing pressure by protists (Newton et al. 2011), and can respond positively to DOC input from phytoplankton because of their ability to degrade complex polymers (Kirchman 2002, Newton et al. 2011, Riemann et al. 2000, Teeling et al. 2012). While we show that fish increased the availability of algae-produced DOC, we do not have data on abundances of ciliates and heterotrophic flagellates to assess the importance of fish- 
induced changes in protistan grazing pressure. However, the observed changes in both abundance and composition of bacteria might have contributed to the increase in microbiallyreprocessed DOC. Taken together, our results suggest that by altering the availability of algae-produced DOC cascading trophic interactions can influence microbial communities, which results in further changes in the DOC pool through altered DOC processing.

The impact of fish on DOC composition varied with time, with strongest effects observed mid-experiment. Such seasonality in the dynamics of DOC composition is expected in systems where multiple biotic and abiotic drivers influence aquatic communities and thus the production and degradation of DOC. For example, the build-up and break-down of phytoplankton blooms is associated with successive availability of different algae-produced DOC compounds and results in a succession of bacterial taxa with different ecological strategies (Teeling et al. 2012). Early- and peak-bloom stages are characterized by high amounts of low-molecular weight DOC from exudation of algae, while the decay and lysis of phytoplankton cells in the post-bloom phase result in the release of higher molecular weight compounds (Buchan et al. 2014). Accordingly, we observed the most pronounced fish effect on low-molecular weight DOC in the period of strongest increase in phytoplankton biomass (Fig. 3a, 3f). Later in the experiment, DOC composition converged to similar values with and without fish, reflecting the reduced divergence in phytoplankton biomass and the declining trend of primary production over time, possibly due a combination of changing temperature (Supplementary material Appendix 1 Fig. A6), light, and nutrient limitation over the course of the season.

Fish could have also influenced DOC dynamics via effects on the benthic community. In many aquatic systems, periphyton and associated bacteria can contribute substantially to ecosystem productivity and carbon cycling (Battin et al. 2016, Lischke et al. 2017, Vander Zanden et al. 2011). Organisms at upper trophic levels can influence the fate of benthosderived carbon via multiple mechanisms: for example, many planktivorous fish supplement 
their diet with benthic prey (Schindler and Scheuerell 2002, Vander Zanden et al. 2011) and translocate carbon and nutrients to the pelagic via excretion (Glaholt and Vanni 2005, Schindler and Scheuerell 2002). Predators could also indirectly affect benthic DOC dynamics by mediating trophic interactions of periphyton with benthic macroinvertebrates or competitive interactions with phytoplankton (Higgins et al. 2014, Shurin et al. 2012). We observed strong negative effects of fish on periphyton biomass mid-experiment (week 7), concurrent with negative fish effects on total DOC concentration (Fig. 3d,e). One possible explanation is that the fish-induced increase in phytoplankton biomass negatively affected periphyton due to increased competition for nutrients, and this negative effect on periphyton resulted in reduced primary production and a slower rate of DOC accumulation. However, testing these hypotheses more directly would require quantifying the relative production rate of both pelagic and benthic algae, and collecting data on all components of the benthic food web (i.e. periphyton, bacteria, macroinvertebrates).

In summary, we found that fish impacted DOC dynamics by altering the abundance and composition of primary producers and bacteria. These food web impacts influenced the production and bioavailability of DOC, as well as DOC compounds originating from microbial reprocessing. Our findings demonstrate that predators can modulate the reactivity of DOC, with likely consequences for microbially-mediated sequestration pathways. Microbial degradation of DOC as a means of permanent carbon storage (i.e. the microbial carbon pump (Jiao et al. 2010, Jiao et al. 2014) is a relatively new concept that has yet to integrate how organisms at upper trophic levels affect carbon sequestration. The large size of the reservoir of persistent DOC in the ocean (Hansell et al. 2009) and its potential for long-term storage (Bauer et al. 1992, Williams and Druffel 1987) has stimulated increasing interest in the processes that influence the reactivity continuum of DOC. Our study suggests that upper trophic levels can influence the reactivity of DOC by altering the biomass, diversity, and composition of algae and bacteria, and thus the production, remineralization, transformation, 
and degradation of DOC. While the direction of these effects will depend on a multitude of factors (e.g. food chain length, community composition, seasonality), our experiment provides some of the first experimental evidence that food web structure can influence the composition of the DOC pool. In light of anthropogenic changes to aquatic ecosystems in general, and to the abundance of predators in particular (Duffy 2003, Estes et al. 2011), it seems prudent to improve our understanding about the effects of food web structure on carbon sequestration pathways.

Acknowledgements - We thank Dany Steiner and Doris Hohmann for help with setting up and sampling of the experiment, Regula Illi for counting the phytoplankton samples, and JeanClaude Walser and the GDC Zurich for help with Illumina library preparation and sequencing.

Funding - We acknowledge the financial support of the SNF grants 31003A-125006 and 31003A-153464/1. NC held a "Juan de la Cierva" postdoctoral grant (FJCI-2014-23064).

\section{Data availability statement}

Data will be uploaded on Dryad upon publication.

\section{References}

Amaral, V., et al. 2016. Strong linkages between DOM optical properties and main clades of aquatic bacteria. - Limnol. Oceanogr. 61: 906-918.

Amon, R. M. W. and Benner, R. 1994. Rapid cycling of high-molecular-weight dissolved organic matter in the ocean. - Nature 369: 549-552.

Amon, R. M. W. and Benner, R. 1996. Bacterial utilization of different size classes of dissolved organic matter. - Limnol. Oceanogr. 41: 41-51. 
Atwood, T. B., et al. 2013. Predator-induced reduction of freshwater carbon dioxide emissions. - Nat. Geosi. 6: 191-194.

Azam, F., et al. 1983. The ecological role of water-column microbes in the sea. - Mar. Ecol. Prog. Ser. 10: 257-263.

Battin, T. J., et al. 2016. The ecology and biogeochemistry of stream biofilms. - Nature Rev. Microbiol. 14: 251-263.

Bauer, J. E., et al. 1992. C-14 activity of dissolved organic carbon fractions in the northcentral Pacific and Sargasso Sea. - Nature 357: 667-670.

Baumgärtner, D. and Rothhaupt, K. O. 2003. Predictive length-dry mass regressions for freshwater invertebrates in a pre-alpine lake littoral. - Int. Rev. Hydrobiol. 88: 453463.

Benner, R. 2003. Molecular indicators of the bioavailability of dissolved organic matter. - In: Findlay, S. E. G. and Sinsabaugh, R. L. (eds.), Aquatic ecosystems: interactivity of dissolved organic matter. Academic Press, pp. 121-137.

Benner, R. and Amon, R. M. W. 2015. The size-reactivity continuum of major bioelements in the ocean. - Annu. Rev. Mar. Sci. 7: 185-205.

Birtel, J., et al. 2015. Estimating bacterial diversity for ecological studies: methods, metrics, and assumptions. - Plos One 10: e0125356.

Bottrell, H. H., et al. 1976. Review of some problems in zooplankton production studies. Norw. J. Zool. 24: 419-456.

Buchan, A., et al. 2014. Master recyclers: features and functions of bacteria associated with phytoplankton blooms. - Nature Rev. Microbiol. 12: 686-698.

Carpenter, S. R., et al. 2001. Trophic cascades, nutrients, and lake productivity: whole-lake experiments. - Ecol. Monogr. 71: 163-186.

Carpenter, S. R., et al. 1985. Cascading trophic interactions and lake productivity. Bioscience 35: 634-639. 
Cawley, K. M., et al. 2012. Characterising the sources and fate of dissolved organic matter in Shark Bay, Australia: a preliminary study using optical properties and stable carbon isotopes. - Mar. Freshwater Res. 63: 1098-1107.

Chari, N., et al. 2013. Fluorescence and absorption characteristics of dissolved organic matter excreted by phytoplankton species of western Bay of Bengal under axenic laboratory condition. - J. Exp. Mar. Biol. Ecol. 445: 148-155.

Coble, P. G. 1996. Characterization of marine and terrestrial DOM in seawater using excitation emission matrix spectroscopy. - Mar. Chem. 51: 325-346.

Culver, D. A., et al. 1985. Biomass of freshwater Crustacean zooplankton from length-weight regressions. - Can. J. Fish. Aquat. Sci. 42: 1380-1390.

Devlin, S. P., et al. 2015. Top consumer abundance influences lake methane efflux. - Nat. Commun. 6: 8787.

Ducklow, H. W., et al. 2001. Upper ocean carbon export and the biological pump. Oceanography 14: 50-58.

Duffy, J. E. 2003. Biodiversity loss, trophic skew and ecosystem functioning. - Ecol. Lett. 6: 680-687.

Dumont, H. J., et al. 1975. The dry weight estimate of biomass in a selection of Cladocera, Copepoda and Rotifera from the plankton, periphyton and benthos of continental waters. - Oecologia 19: 75-97.

Eppley, R. W. and Peterson, B. J. 1979. Particulate organic matter flux and planktonic new production in the deep ocean. - Nature 282: 677-680.

Estes, J. A., et al. 2011. Trophic downgrading of planet earth. - Science 333: 301-306.

Fellman, J. B., et al. 2011. Source, biogeochemical cycling, and fluorescence characteristics of dissolved organic matter in an agro-urban estuary. - Limnol. Oceanogr. 56: 243256. 
Findlay, S. E. G. and Sinsabaugh, R. L. 2003. Aquatic ecosystems: interactivity of dissolved organic matter. - Academic Press.

Flanagan, K. M., et al. 2006. Freshwater food webs control carbon dioxide saturation through sedimentation. - Glob. Change Biol. 12: 644-651.

Giroldo, D. and Vieira, A. A. H. 2005. Polymeric and free sugars released by three phytoplanktonic species from a freshwater tropical eutrophic reservoir. - J. Plankton Res. 27: 695-705.

Glaholt, S. P. and Vanni, M. J. 2005. Ecological responses to simulated benthic-derived nutrient subsidies mediated by omnivorous fish. - Freshw. Biol. 50: 1864-1881.

Graeber, D., et al. 2012. Agriculture has changed the amount and composition of dissolved organic matter in Central European headwater streams. - Sci. Total Environ. 438: 435446.

Hansell, D. A., et al. 2009. Dissolved organic matter in the ocean. A controversy stimulates new insights. - Oceanography 22: 202-211.

Harmon, L. J., et al. 2009. Evolutionary diversification in stickleback affects ecosystem functioning. - Nature 458: 1167-1170.

Helms, J. R., et al. 2008. Absorption spectral slopes and slope ratios as indicators of molecular weight, source, and photobleaching of chromophoric dissolved organic matter. - Limnol. Oceanogr. 53: 955-969.

Higgins, S. N., et al. 2014. Potential for large-bodied zooplankton and dreissenids to alter the productivity and autotrophic structure of lakes. - Ecology 95: 2257-2267.

Huguet, A., et al. 2009. Properties of fluorescent dissolved organic matter in the Gironde Estuary. - Org. Geochem. 40: 706-719.

Jakobsen, T. S., et al. 2004. Cascading effect of three-spined stickleback Gasterosteus aculeatus on community composition, size, biomass and diversity of phytoplankton in shallow, eutrophic brackish lagoons. - Mar. Ecol. Prog. Ser. 279: 305-309. 
Jiao, N., et al. 2010. Microbial production of recalcitrant dissolved organic matter: long-term carbon storage in the global ocean. - Nature Rev. Microbiol. 8: 593-599.

Jiao, N., et al. 2014. Mechanisms of microbial carbon sequestration in the ocean - future research directions. - Biogeosciences 11: 5285-5306.

Jürgens, K., et al. 1999. Morphological and compositional changes in a planktonic bacterial community in response to enhanced protozoan grazing. - Appl. Environ. Microb. 65: 1241-1250.

Kirchman, D. L. 2002. The ecology of Cytophaga-Flavobacteria in aquatic environments. FEMS Microbiol. Ecol. 39: 91-100.

Kothawala, D. N., et al. 2013. Inner filter correction of dissolved organic matter fluorescence. - Limnol. Oceanogr.-Meth. 11: 616-630.

Kuczynski, J., et al. 2011. Using QIIME to analyze 16S rRNA gene sequences from microbial communities. - Curr. Protoc. Bioinform. 36: 10.17.11-10.17.20.

Lambert, T., et al. 2016. Along-stream transport and transformation of dissolved organic matter in a large tropical river. - Biogeosciences 13: 2727-2741.

Lampert, W. 1978. Release of dissolved organic carbon by grazing zooplankton. - Limnol. Oceanogr. 23: 831-834.

Limberger, R., et al. 2017. Ecosystem flux and biotic modification as drivers of metaecosystem dynamics. - Ecology 98: 1082-1092.

Lischke, B., et al. 2017. Benthic carbon is inefficiently transferred in the food webs of two eutrophic shallow lakes. - Freshw. Biol. 62: 1693-1706.

Lliros, M., et al. 2008. High archaeal richness in the water column of a freshwater sulfurous karstic lake along an interannual study. - FEMS Microbiol. Ecol. 66: 331-342.

Logue, J. B., et al. 2016. Experimental insights into the importance of aquatic bacterial community composition to the degradation of dissolved organic matter. - Isme J. 10: $533-545$. 
Loreau, M., et al. 2003. Meta-ecosystems: a theoretical framework for a spatial ecosystem ecology. - Ecol. Lett. 6: 673-679.

Marques, D. A. 2016. Population genomics of adaptive radiation: a threespine stickleback perspective. - PhD thesis, University of Bern.

Massicotte, P. and Markager, S. 2016. Using a Gaussian decomposition approach to model absorption spectra of chromophoric dissolved organic matter. - Mar. Chem. 180: 2432.

McKnight, D. M., et al. 2001. Spectrofluorometric characterization of dissolved organic matter for indication of precursor organic material and aromaticity. - Limnol. Oceanogr. 46: 38-48.

Mostovaya, A., et al. 2016. Effects of compositional changes on reactivity continuum and decomposition kinetics of lake dissolved organic matter. - J. Geophys. Res-Biogeo. 121: $1733-1746$.

Murphy, K. R., et al. 2010. Measurement of dissolved organic matter fluorescence in aquatic environments: an interlaboratory comparison. - Environ. Sci. Technol. 44: 9405-9412.

Murphy, K. R., et al. 2013. Fluorescence spectroscopy and multi-way techniques. PARAFAC. - Anal. Methods 5: 6557-6566.

Murphy, K. R., et al. 2008. Distinguishing between terrestrial and autochthonous organic matter sources in marine environments using fluorescence spectroscopy. - Mar. Chem. 108: $40-58$.

Newton, R. J., et al. 2011. A guide to the natural history of freshwater lake bacteria. Microbiol. Mol. Biol. R. 75: 14-49.

Nizzetto, L., et al. 2012. Biological pump control of the fate and distribution of hydrophobic organic pollutants in water and plankton. - Environ. Sci. Technol. 46: 3204-3211.

Ohno, T. 2002. Fluorescence inner-filtering correction for determining the humification index of dissolved organic matter. - Environ. Sci. Technol. 36: 742-746. 
Osburn, C. L., et al. 2016. Optical proxies for terrestrial dissolved organic matter in estuaries and coastal waters. - Front. Mar. Sci. 2.

Pace, M. L., et al. 1990. Planktonic community structure determines the fate of bacterial production in a temperate lake. - Limnol. Oceanogr. 35: 795-808.

Pernthaler, J. 2005. Predation on prokaryotes in the water column and its ecological implications. - Nature Rev. Microbiol. 3: 537-546.

R Core Team. 2015. R: A language and environment for statistical computing. R foundation for statistical computing.

Riemann, L., et al. 2000. Dynamics of bacterial community composition and activity during a mesocosm diatom bloom. - Appl. Environ. Microb. 66: 578-587.

Ruttner-Kolisko, A. 1977. Suggestions for biomass calculations of plankton rotifers. - Ergeb. Limnol. 8: 71-76.

Saarenheimo, J., et al. 2016. Bacterial community response to changes in a tri-trophic cascade during a whole-lake fish manipulation. - Ecology 97: 684-693.

Schindler, D. E., et al. 1997. Influence of food web structure on carbon exchange between lakes and the atmosphere. - Science 277: 248-251.

Schindler, D. E. and Scheuerell, M. D. 2002. Habitat coupling in lake ecosystems. - Oikos 98 : 177-189.

Schmitz, O. J., et al. 2014. Animating the carbon cycle. - Ecosystems 17: 344-359.

Shurin, J. B., et al. 2012. Warming shifts top-down and bottom-up control of pond food web structure and function. - Phil. Trans. R. Soc. B 367: 3008-3017.

Shutova, Y., et al. 2014. Spectroscopic characterisation of dissolved organic matter changes in drinking water treatment: from PARAFAC analysis to online monitoring wavelengths. - Water Res. 54: 159-169. 
Simek, K., et al. 2011. Alga-derived substrates select for distinct betaproteobacterial lineages and contribute to niche separation in Limnohabitans strains. - Appl. Environ. Microb. 77: 7307-7315.

Simek, K., et al. 2014. A finely tuned symphony of factors modulates the microbial food web of a freshwater reservoir in spring. - Limnol. Oceanogr. 59: 1477-1492.

Stedmon, C. A. and Markager, S. 2005. Tracing the production and degradation of autochthonous fractions of dissolved organic matter by fluorescence analysis. Limnol. Oceanogr. 50: 1415-1426.

Stedmon, C. A., et al. 2003. Tracing dissolved organic matter in aquatic environments using a new approach to fluorescence spectroscopy. - Mar. Chem. 82: 239-254.

Stibor, H., et al. 2004. Copepods act as a switch between alternative trophic cascades in marine pelagic food webs. - Ecol. Lett. 7: 321-328.

Sullam, K. E., et al. 2017. The effect of top-predator presence and phenotype on aquatic microbial communities. - Ecol. Evol. 7: 1572-1582.

Teeling, H., et al. 2012. Substrate-Controlled Succession of Marine Bacterioplankton Populations Induced by a Phytoplankton Bloom. - Science 336: 608-611.

Vander Zanden, M. J., et al. 2011. Fish Reliance on Littoral-Benthic Resources and the Distribution of Primary Production in Lakes. - Ecosystems 14: 894-903.

Vanni, M. J., et al. 2006. Nutrient cycling by fish supports relatively more primary production as lake productivity increases. - Ecology 87: 1696-1709.

Vanni, M. J. and Layne, C. D. 1997. Nutrient recycling and herbivory as mechanisms in the "top-down" effect of fish on algae in lakes. - Ecology 78: 21-40.

Walker, S. A., et al. 2009. The use of PARAFAC modeling to trace terrestrial dissolved organic matter and fingerprint water masses in coastal Canadian Arctic surface waters. - J. Geophys. Res-Biogeo. 114. 

600

601

602

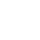

Williams, P. M. and Druffel, E. R. M. 1987. Radiocarbon in dissolved organic matter in the central North Pacific Ocean. - Nature 330: 246-248.

Yamashita, Y., et al. 2013. Evaluating the distribution of terrestrial dissolved organic matter in a complex coastal ecosystem using fluorescence spectroscopy. - Cont. Shelf Res. 66: $136-144$.

Yamashita, Y., et al. 2010. Fluorescence characteristics of dissolved organic matter in the deep waters of the Okhotsk Sea and the northwestern North Pacific Ocean. - Deep-Sea Res. Pt. II 57: 1478-1485.

Zöllner, E., et al. 2009. Effect of zooplankton-mediated trophic cascades on marine microbial food web components (bacteria, nanoflagellates, ciliates). - Limnol. Oceanogr. 54: $262-275$.

Zöllner, E., et al. 2003. Cascading predation effects of Daphnia and copepods on microbial food web components. - Freshw. Biol. 48: 2174-2193. 


\section{Figure legends}

Fig. 1: Major pathways of organic carbon in aquatic systems. Organisms influence both the flux (arrows) and the sequestration (trapezoids) of organic carbon. The carbon fixed by algae is passed to higher trophic levels through feeding interactions (algae-based food chain). A part of the primary production is released as dissolved organic carbon (DOC) via exudation of algae, sloppy feeding and excretion of animals (arrows not shown), and microbial decomposition of organisms. Bacteria consume bioavailable DOC and pass it back to higher trophic levels (microbial loop). Both of these two trophic pathways, the algae-based food chain and the microbial loop, result in remineralization of carbon, but can also lead to sequestration of carbon via export of particulate organic carbon (POC) to the sediment (biological carbon pump), and via microbial degradation of reactive to less reactive DOC (microbial carbon pump), ultimately resulting in the production of recalcitrant DOC (RDOC).

Fig. 2: Effects of fish on plankton biomass and diversity. Data are from the end of the experiment (week 17 for bacterial abundance, week 19 for all other parameters). (a) Biomass of zooplankton (Zoo) and phytoplankton (Phyto), and abundance of bacteria (Bac), (b) diversity of zooplankton, phytoplankton, and bacteria. Significant effects of the fish treatment are denoted with $* * * \mathrm{P}<0.001, * * \mathrm{P}<0.01, * \mathrm{P}<0.05$. Values are mean $\pm \mathrm{SE}, \mathrm{N}=20$.

Fig. 3: Time series of biotic and DOC parameters. (a) Phytoplankton biomass as chlorophyll-a, (b) number of bacteria, (c) net ecosystem productivity (NEP), (d) periphyton biomass, (e) dissolved organic carbon (DOC), and (f) slope ratio. Higher slope ratios indicate a higher proportion of low-molecular weight DOC compounds. Significant effects of the fish treatment at individual weeks are denoted with $*(P<0.05)$. Values are mean $\pm \mathrm{SE}, \mathrm{N}=20$. 
(a) Week 9 of the experiment, (b) end of experiment (week 17 for bacterial abundance, week 19 for all other parameters). Values are log-response ratios $\pm 95 \%$ confidence intervals, after z-transformation of the data. Positive values indicate a positive effect of fish. Significant

632 effects of the fish treatment are denoted with *** $\mathrm{P}<0.001, * * \mathrm{P}<0.01, * \mathrm{P}<0.05$. Note that 633 zooplankton biomass was not measured at week 9. Zoo: Zooplankton biomass; Phyto:

634 phytoplankton biomass measured as chlorophyll-a; Bac: number of bacteria; FI: fluorescence 635 index; BIX: freshness index; HIX: humification index; C1-C5: DOC components identified 636 with PARAFAC modelling (calculations based on absolute values normalized by DOC 637 concentration), sorted by relative proportion. 


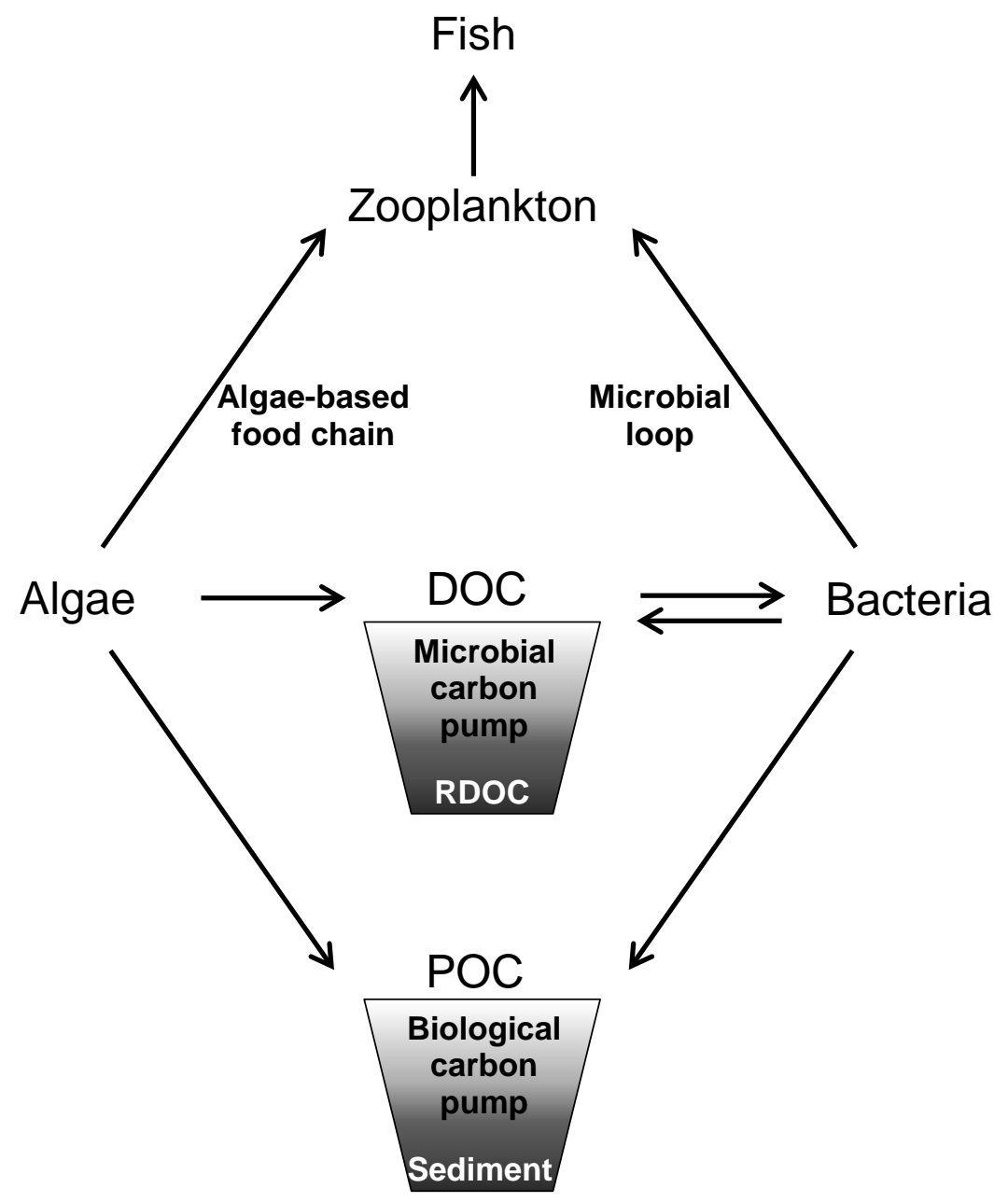




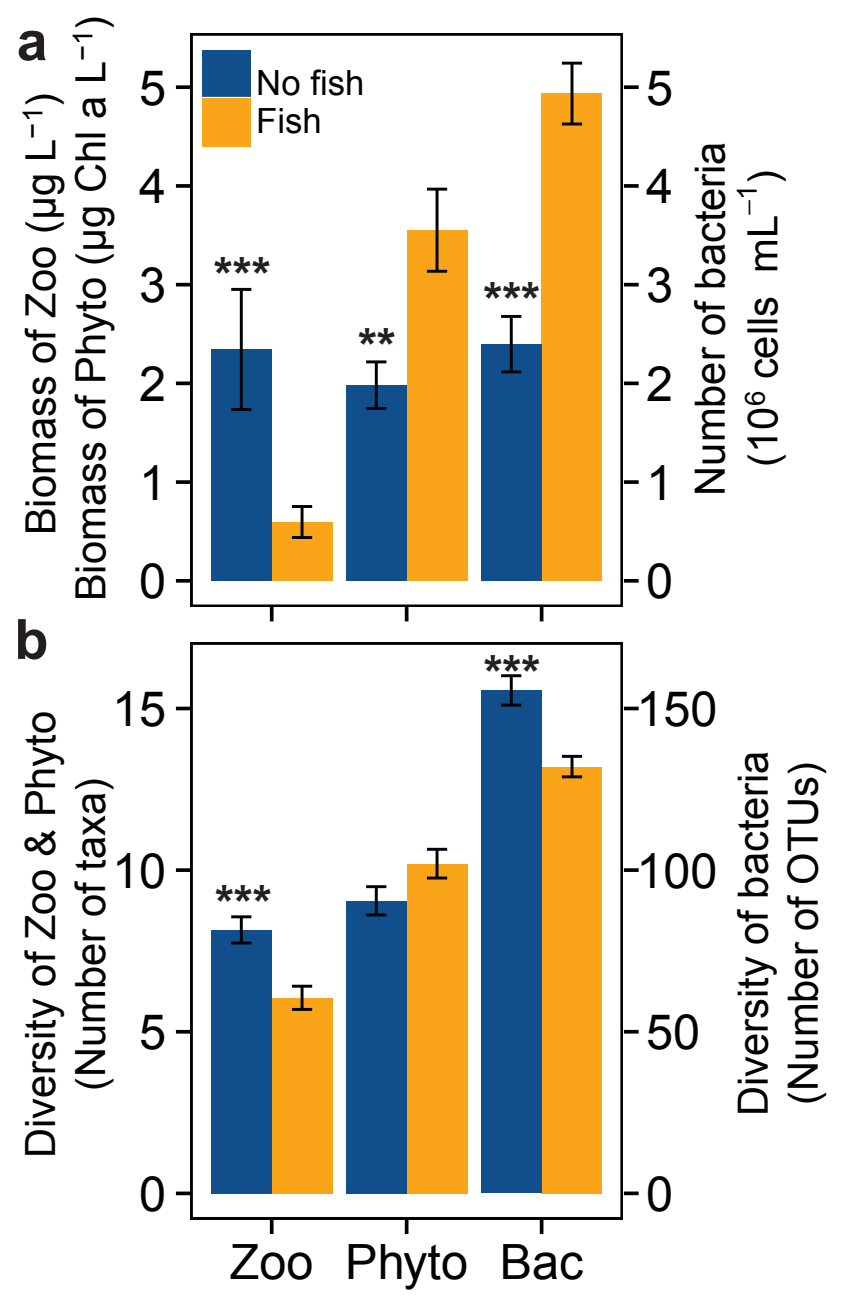



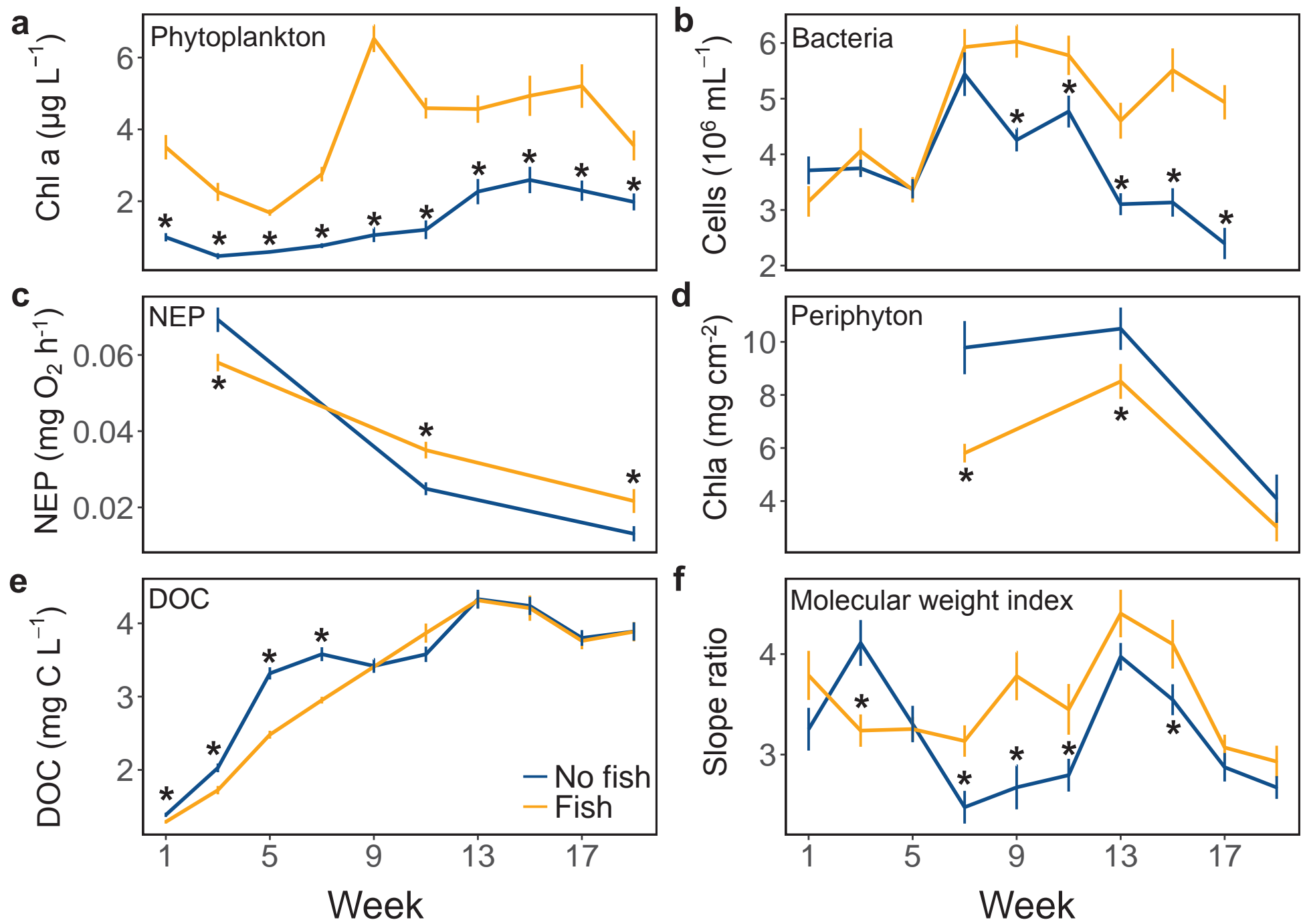


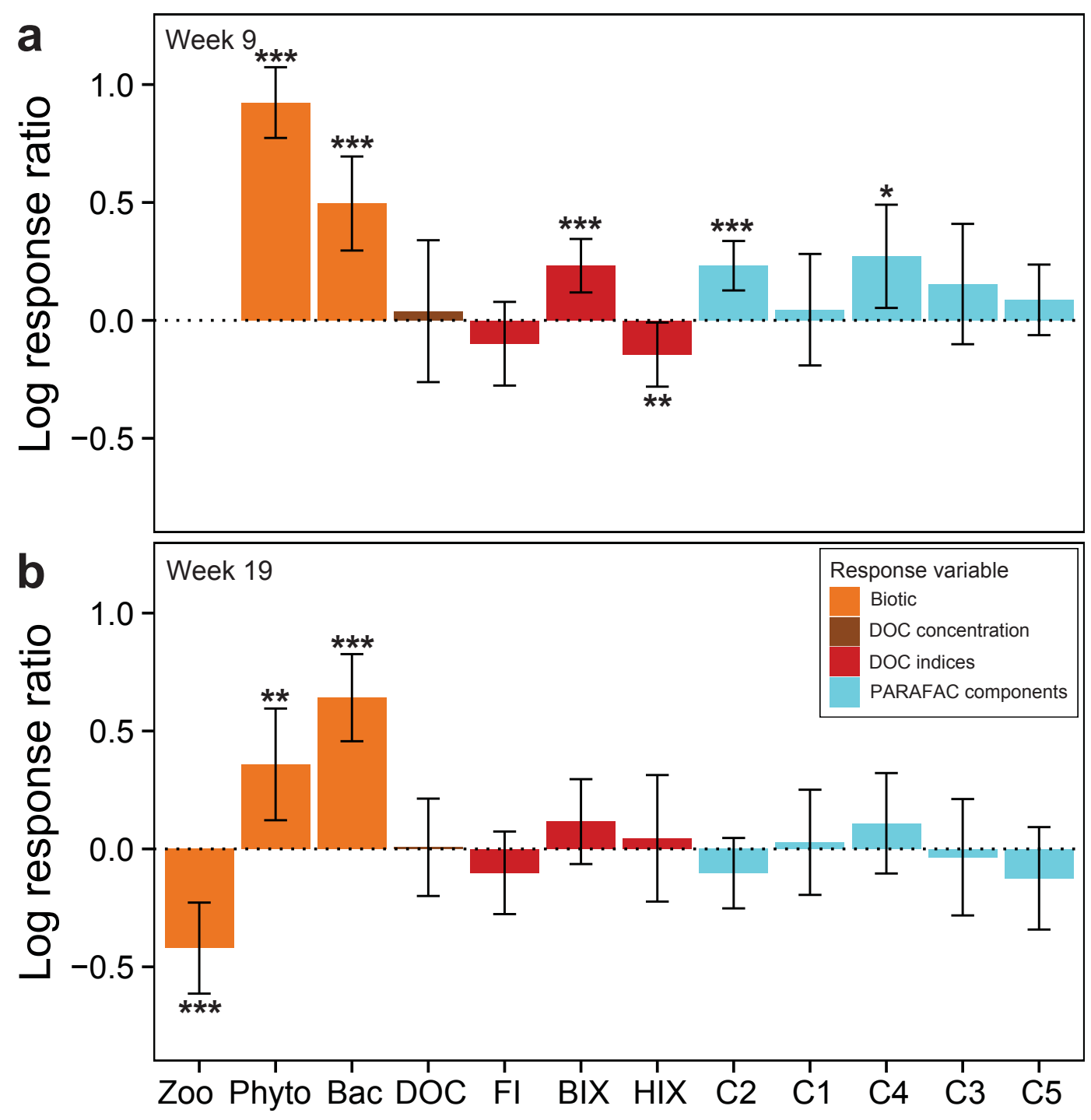




\section{Supplemental tables and figures}

Table A1: DOC parameters (partly from (Helms et al. 2008, Fellman et al. 2010)).

References for characterization of the PARAFAC components are provided in the main text.

\begin{tabular}{|c|c|c|}
\hline Parameter & Calculation & Description \\
\hline \multicolumn{3}{|l|}{ Diagnostic indices } \\
\hline SR (Slope ratio) & $\begin{array}{l}\text { slope } 275-295 \mathrm{~nm} / \text { slope }_{350-} \\
400 \mathrm{~nm}\end{array}$ & $\begin{array}{l}\text { Higher SR indicates higher proportion of low- } \\
\text { molecular weight DOC compounds }\end{array}$ \\
\hline $\begin{array}{l}\text { FI (Fluorescence } \\
\text { index) }\end{array}$ & $\begin{array}{l}\mathrm{Em}_{450 \mathrm{~nm}} / \mathrm{Em}_{500 \mathrm{~nm}} \\
(\mathrm{Ex}: 370 \mathrm{~nm})\end{array}$ & $\begin{array}{l}\text { Higher FI indicates higher proportion of } \\
\text { microbially (rather than terrestrially) derived } \\
\text { DOC. }\end{array}$ \\
\hline $\begin{array}{l}\text { HIX (Humification } \\
\text { index) }\end{array}$ & $\begin{array}{l}\mathrm{Em}_{435-480 \mathrm{~nm}} / \mathrm{Em}_{300-445 \mathrm{~nm}} \\
(\mathrm{Ex}: 254 \mathrm{~nm})\end{array}$ & $\begin{array}{l}\text { Higher HIX indicates higher proportion of } \\
\text { humic substances. }\end{array}$ \\
\hline $\begin{array}{l}\text { BIX (Freshness } \\
\text { index) }\end{array}$ & $\begin{array}{l}\mathrm{Em}_{380 \mathrm{~nm}} / \mathrm{Em}_{430 \mathrm{~nm}} \\
(\mathrm{Ex}: 310 \mathrm{~nm})\end{array}$ & $\begin{array}{l}\text { Higher BIX indicates higher proportion of } \\
\text { recently produced DOC. }\end{array}$ \\
\hline \multicolumn{3}{|l|}{ DOC components } \\
\hline $\mathrm{C} 1$ & PARAFAC & Humic-like, terrestrial origin \\
\hline $\mathrm{C} 2$ & PARAFAC & $\begin{array}{l}\text { Protein-like, microbial origin, related with } \\
\text { bioavailable compounds and algal sources }\end{array}$ \\
\hline $\mathrm{C} 3$ & PARAFAC & Humic-like, terrestrial origin \\
\hline $\mathrm{C} 4$ & PARAFAC & Protein-like, microbial origin \\
\hline $\mathrm{C} 5$ & PARAFAC & Humic-like, microbial origin \\
\hline
\end{tabular}


Table A2: Results of linear mixed effects models testing for effects of fish on biotic and abiotic ecosystem properties. Data are from mid-experiment (week 7 for periphyton, week 11 for net ecosystem productivity (NEP) and respiration, week 13 for sedimentation, week 9 for all other parameters) and from the end of the experiment (week 17 for abundance of bacteria, week 19 for all other parameters). Abundance of bacteria and biomass of phyto- and zooplankton were log-transformed prior to statistical analyses. DOC parameters include total DOC concentration (DOC), slope ratio (SR), fluorescence index (FI), freshness index (BIX), humification index (HIX), and five DOC components (C1-C5) identified with PARAFAC modelling from emission-excitation matrices. Tests on $\mathrm{C} 1-\mathrm{C} 5$ are based on absolute values normalized by DOC concentration, and on relative proportions, respectively. Bold font denotes results with $P<0.05$. Effect of fish specified as positive $(+)$, negative $(-)$, or not significant (n.s.).

\begin{tabular}{|c|c|c|c|c|c|c|}
\hline & \multicolumn{3}{|c|}{ Mid-experiment } & \multicolumn{3}{|c|}{ End of experiment } \\
\hline & F-value & P-value & Effect & F-value & P-value & Effect \\
\hline \multicolumn{7}{|c|}{ Biomass/Abundance } \\
\hline Bacteria & 27.731 & $<0.001$ & + & 49.993 & $<0.001$ & + \\
\hline Phytoplankton & 252.97 & $<0.001$ & + & 9.968 & 0.005 & + \\
\hline Zooplankton & & & & 31.04 & $<0.001$ & - \\
\hline Periphyton & 17.374 & $<0.001$ & - & 1.221 & 0.283 & n.s. \\
\hline \multicolumn{7}{|l|}{ Diversity } \\
\hline Bacteria & & & & 28.49 & $<0.001$ & - \\
\hline Phytoplankton & & & & 3.392 & 0.081 & n.s. \\
\hline Zooplankton & & & & 36.59 & $<0.001$ & - \\
\hline \multicolumn{7}{|c|}{ Ecosystem functions } \\
\hline NEP & 14.426 & 0.001 & + & 5.314 & 0.033 & + \\
\hline Respiration & 5.612 & 0.029 & + & 1.302 & 0.268 & n.s. \\
\hline Sedimentation & 0.882 & 0.36 & n.s. & 0.181 & 0.676 & n.s. \\
\hline \multicolumn{7}{|c|}{ DOC parameters } \\
\hline DOC & 0.009 & 0.925 & n.s. & 0 & 0.988 & n.s. \\
\hline SR & 20.257 & $<0.001$ & + & 1.778 & 0.198 & n.s. \\
\hline FI & 2.877 & 0.107 & n.s. & 1.701 & 0.208 & n.s. \\
\hline BIX & 20.141 & $<0.001$ & + & 0.097 & 0.759 & n.s. \\
\hline HIX & 8.562 & 0.009 & - & 0.02 & 0.89 & n.s. \\
\hline C1 (absolute) & 0.087 & 0.772 & n.s. & 0.107 & 0.748 & n.s. \\
\hline C2 (absolute) & 16.22 & $<0.001$ & + & 2.663 & 0.119 & n.s. \\
\hline C3 (absolute) & 0.795 & 0.384 & n.s. & 0.089 & 0.768 & n.s. \\
\hline C4 (absolute) & 4.575 & 0.046 & + & 1.257 & 0.276 & n.s. \\
\hline C5 (absolute) & 1.522 & 0.234 & n.s. & 1.645 & 0.215 & n.s. \\
\hline C1 (relative) & 22.542 & $<0.001$ & - & 2.527 & 0.128 & n.s. \\
\hline C2 (relative) & 2.139 & 0.161 & n.s. & 0.423 & 0.523 & n.s. \\
\hline C3 (relative) & 3.601 & 0.074 & n.s. & 0.024 & 0.877 & n.s. \\
\hline C4 (relative) & 2.516 & 0.130 & n.s. & 5.029 & $\mathbf{0 . 0 3 7}$ & + \\
\hline C5 (relative) & 1.233 & 0.281 & n.s. & 1.661 & 0.213 & n.s. \\
\hline
\end{tabular}


Table A3: Results of linear mixed effects models testing for effects of fish and time on abundances of bacteria (Bac), phytoplankton biomass measured as chlorophyll-a (Phyto), DOC concentration, and slope ratio (SR). Abundance of bacteria and biomass of phytoplankton were log-transformed prior to statistical analyses. Bold font denotes results with $\mathrm{P}<0.05$.

\begin{tabular}{lrrrrrr}
\hline & \multicolumn{2}{c}{ Fish } & \multicolumn{2}{c}{ Week } & \multicolumn{2}{c}{ Fish $\times$ Week } \\
\cline { 2 - 7 } & F-value & P-value & F-value & P-value & F-value & P-value \\
\hline Bac & 41.359 & $<\mathbf{0 . 0 0 1}$ & 19.047 & $<\mathbf{0 . 0 0 1}$ & 10.556 & $<\mathbf{0 . 0 0 1}$ \\
Phyto & 175.656 & $<\mathbf{0 . 0 0 1}$ & 29.956 & $<\mathbf{0 . 0 0 1}$ & 7.525 & $<\mathbf{0 . 0 0 1}$ \\
DOC & 5.147 & $\mathbf{0 . 0 3 5}$ & 261.611 & $<\mathbf{0 . 0 0 1}$ & 7.792 & $<\mathbf{0 . 0 0 1}$ \\
SR & 14.852 & $\mathbf{0 . 0 0 1}$ & 12.085 & $<\mathbf{0 . 0 0 1}$ & 4.048 & $<\mathbf{0 . 0 0 1}$ \\
\hline
\end{tabular}


Table A4: Results of db-RDA testing for the effects of fish on the composition of bacteria, phyto- and zooplankton. Abundances were Hellinger-transformed prior to analyses. P-values were calculated using 10,000 permutations. Bold font denotes results with $\mathrm{P}<0.05$.

\begin{tabular}{lcc}
\hline Group & F-value & P-value \\
\hline Bacteria & 3.557 & $<\mathbf{0 . 0 0 1}$ \\
Phytoplankton & 9.02 & $\mathbf{< 0 . 0 0 1}$ \\
Zooplankton & 11.909 & $\mathbf{< 0 . 0 0 1}$ \\
\hline
\end{tabular}


Table A5: Results of db-RDA testing for the effect of fish on the composition of the DOC pool. Absolute values of the five PARAFAC components were used as response variables. Pvalues were calculated using 10,000 permutations. Bold font denotes results with $\mathrm{P}<0.05$.

\begin{tabular}{lcr}
\hline Group & F-value & P-value \\
\hline Week 1 & 0.300 & 0.785 \\
Week 9 & 7.096 & $\mathbf{0 . 0 0 7}$ \\
Week 19 & 1.964 & 0.112 \\
\hline
\end{tabular}




\section{References}

Fellman, J. B., E. Hood, and R. G. M. Spencer. 2010. Fluorescence spectroscopy opens new windows into dissolved organic matter dynamics in freshwater ecosystems: A review. Limnology and Oceanography 55:2452-2462.

Helms, J. R., A. Stubbins, J. D. Ritchie, E. C. Minor, D. J. Kieber, and K. Mopper. 2008. Absorption spectral slopes and slope ratios as indicators of molecular weight, source, and photobleaching of chromophoric dissolved organic matter. Limnology and Oceanography 53:955-969. 


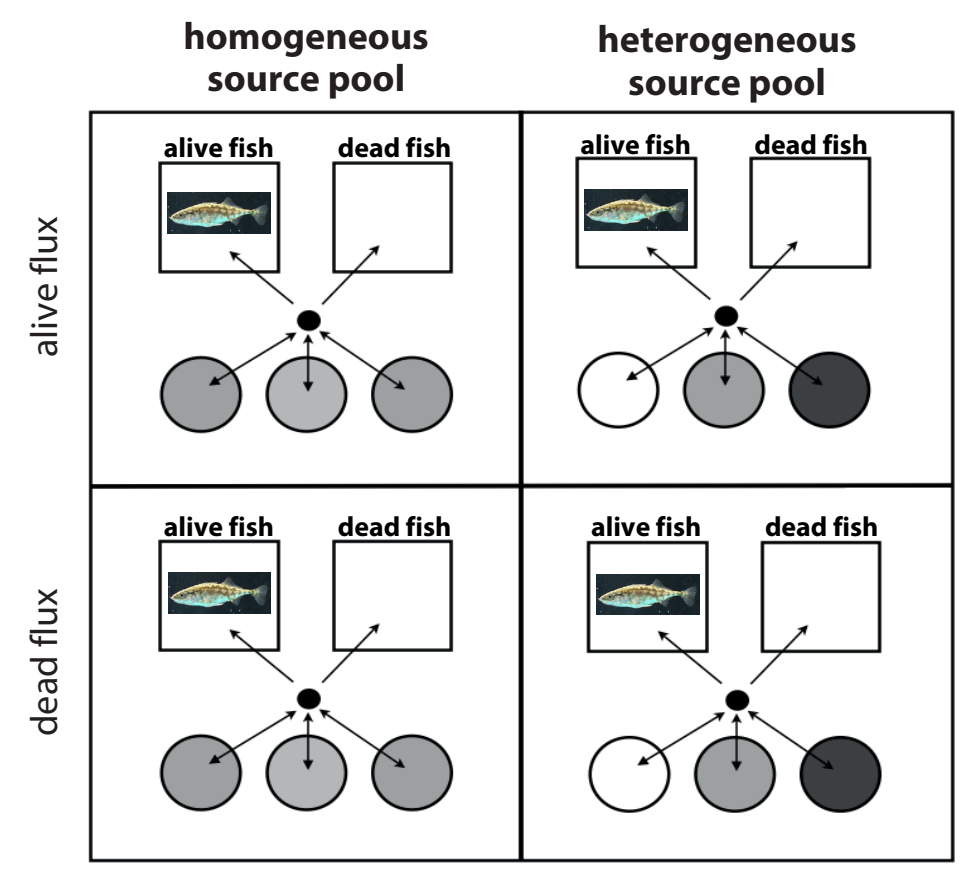

Fig. A1: Full experimental design. The experiment that we present in the main text was part of a larger mesocosm experiment about effects of ecosystem flux and environmental heterogeneity on aquatic ecosystems. We here describe the full design of the experiment, but note that (i) the results presented in the main text only include data from those mesocosms that are depicted as squares in the scheme, and (ii) the analyses in the main text focus on analyses of the fish contrast, irrespective of the flux and heterogeneity treatment.

We set up 20 pairs of mesocosms of $1000 \mathrm{~L}$ volume (squares). One mesocosm of each pair was stocked with six living stickleback, the other one with six dead stickleback. Once every other week, each pair of tanks received water from three donor ecosystems (i.e. three mesocosms of $300 \mathrm{~L}$ water volume; circles in the scheme). To this end, water from each of the three donor ecosystems was sampled, mixed in a barrel (small circle in the scheme), and $1 \mathrm{~L}$ was added to each of the two large tanks. The three small tanks were connected with each other through bi-weekly exchanges of $300 \mathrm{~mL}$ water, but did not receive any input from the large tanks. In a $2 \times 2$ design, we manipulated the nature of this ecosystem flux (alive or dead) and the heterogeneity of the source pool (homogeneous or heterogeneous). In the treatment with dead flux, the organisms in the water were killed by autoclaving prior to addition to the large tanks and exchange among the small tanks, respectively. The three donor ecosystems were either identical in environmental conditions (homogenous source pool) or differed in nutrient and DOC loading (heterogeneous source pool). In the heterogeneous treatment, one of the three donor ecosystems received high nutrient input, one received DOC additions, and one received low input of nutrients and DOC. In the homogeneous treatment, all three donor ecosystems received intermediate levels of nutrient and DOC input (see Limberger et al. (2017) for further details on the three donor ecosystems). The two large tanks did not receive additions of nutrients and DOC other than through addition of water from the three donor ecosystems. We here focus our analyses on the fish contrast, irrespective of the flux and heterogeneity treatment. Almost none of the response variables were affected by the manipulation of flux and heterogeneity of the donor ecosystems, possibly reflecting the low amount of water added $(0.1 \%$ of the water volume every other week). However, to take into account the non-independence of the two tanks of a pair, because of spatial proximity and connectivity to the same donor ecosystem, we included pair of tank (i.e. same donor ecosystem) as a random factor in our statistical analyses. 

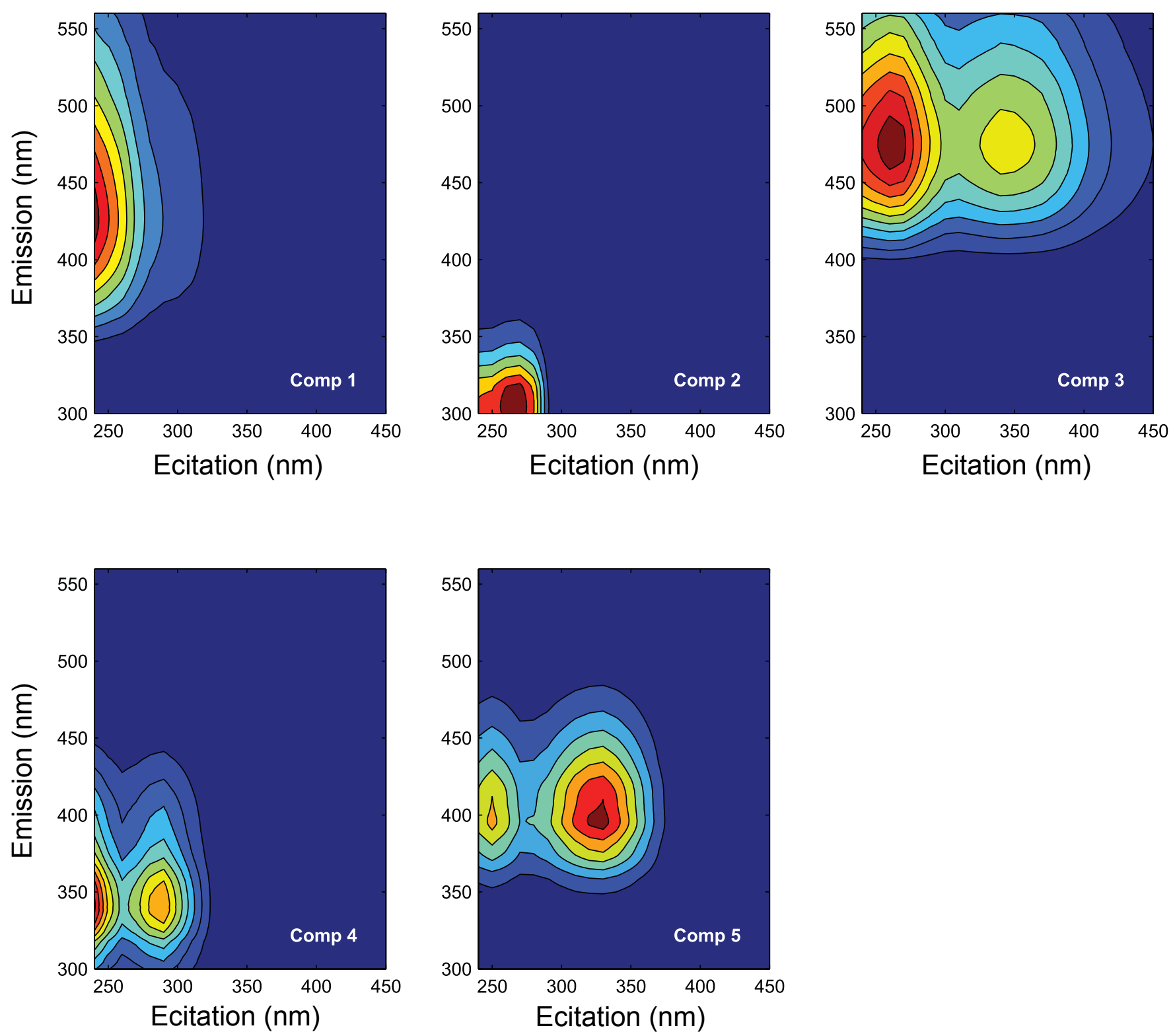

Fig. A2: Five DOC components identified from excitation-emission matrices with PARAFAC modelling. 

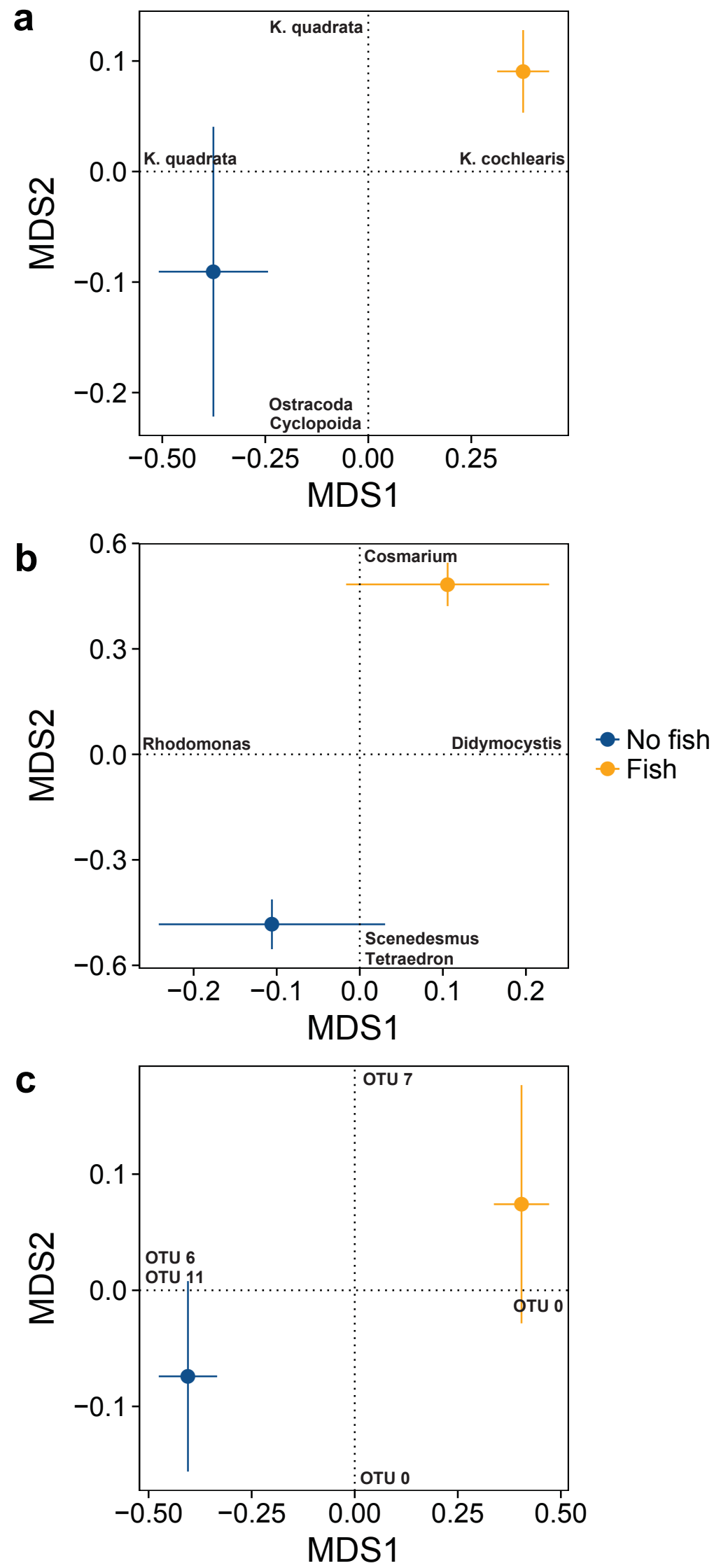

Fig. A3: Principle Coordinates Analysis of Hellinger-transformed abundance data. (a) Zooplankton (i.e. Crustacea and rotifers), (b) phytoplankton, and (c) bacteria. Taxa with highest loadings on the first two axes are plotted in the graph. Zooplankton taxa with high loadings were the rotifers Keratella quadrata and Keratella cochlearis, and the crustacean groups Ostracoda and Cyclopoida. Phytoplankton taxa with high loadings were Scenedesmus, Tetraedron, and Didymocystis (all Chlorophyta), Cosmarium (Charophyta), and Rhodomonas (Cryptophyta). Bacterial OTUs with high loadings were OTU 0 (Family Oxalobacteraceae, Class Betaproteo-bacteria), OTU 6 (Family Rhodocyclaceae, Class Betaproteobacteria), OTU 7 (Family Hyphomicrobiaceae, Class Alphaproteobacteria), and OTU 11 (Family Comamonadaceae, Class Betaproteobacteria). 

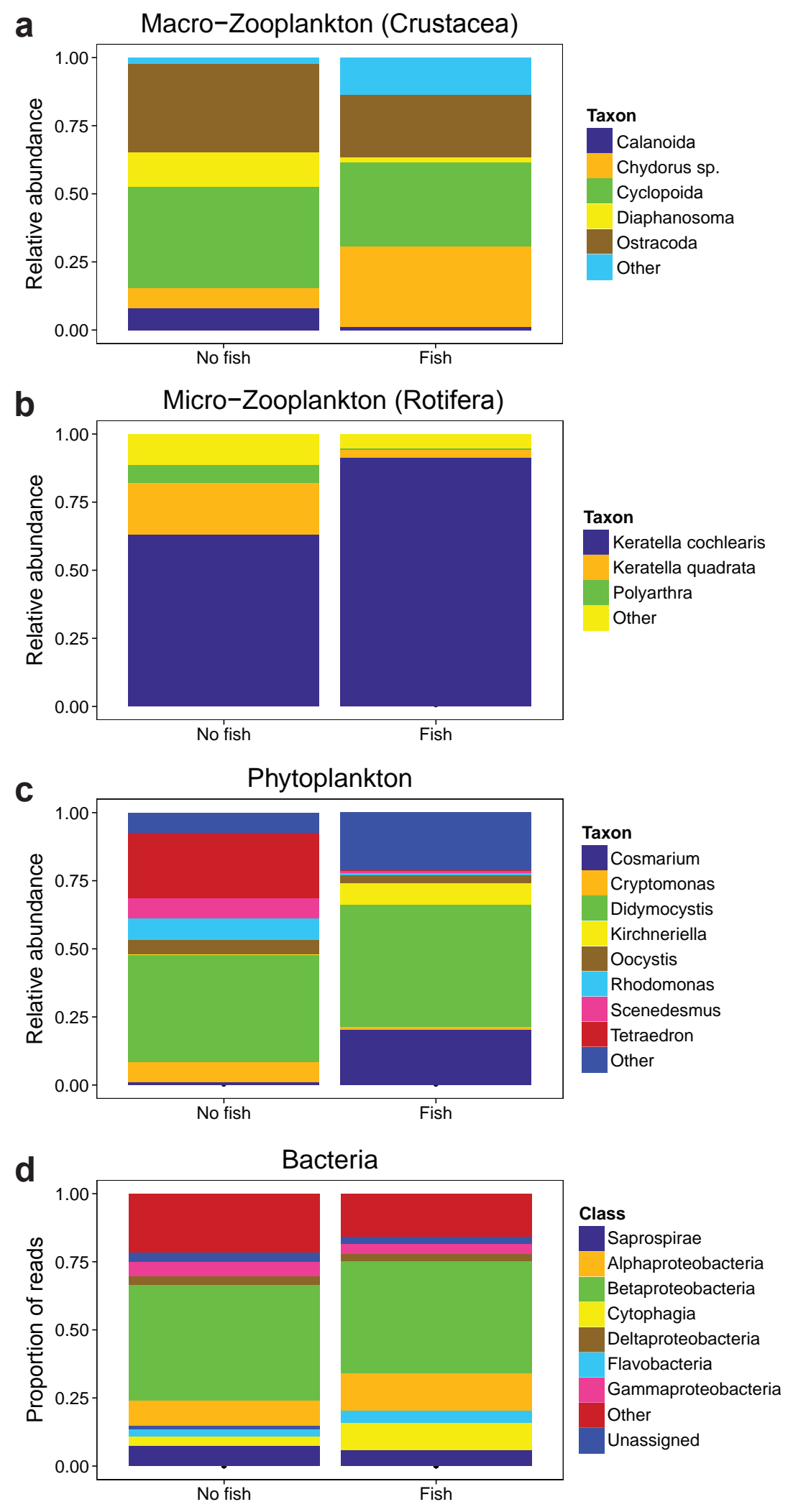

Fig. A4: Effect of fish on the composition of the plankton. Relative abundances of (a) taxa of macro-zooplankton (i.e. Crustacea), (b) taxa of micro-zooplankton (i.e. rotifers), (c) taxa of phytoplankton, and (d) proportion of reads of bacterial classes. Rare taxa were lumped together as "other". Values are averages across tanks, $\mathrm{N}=20$. 


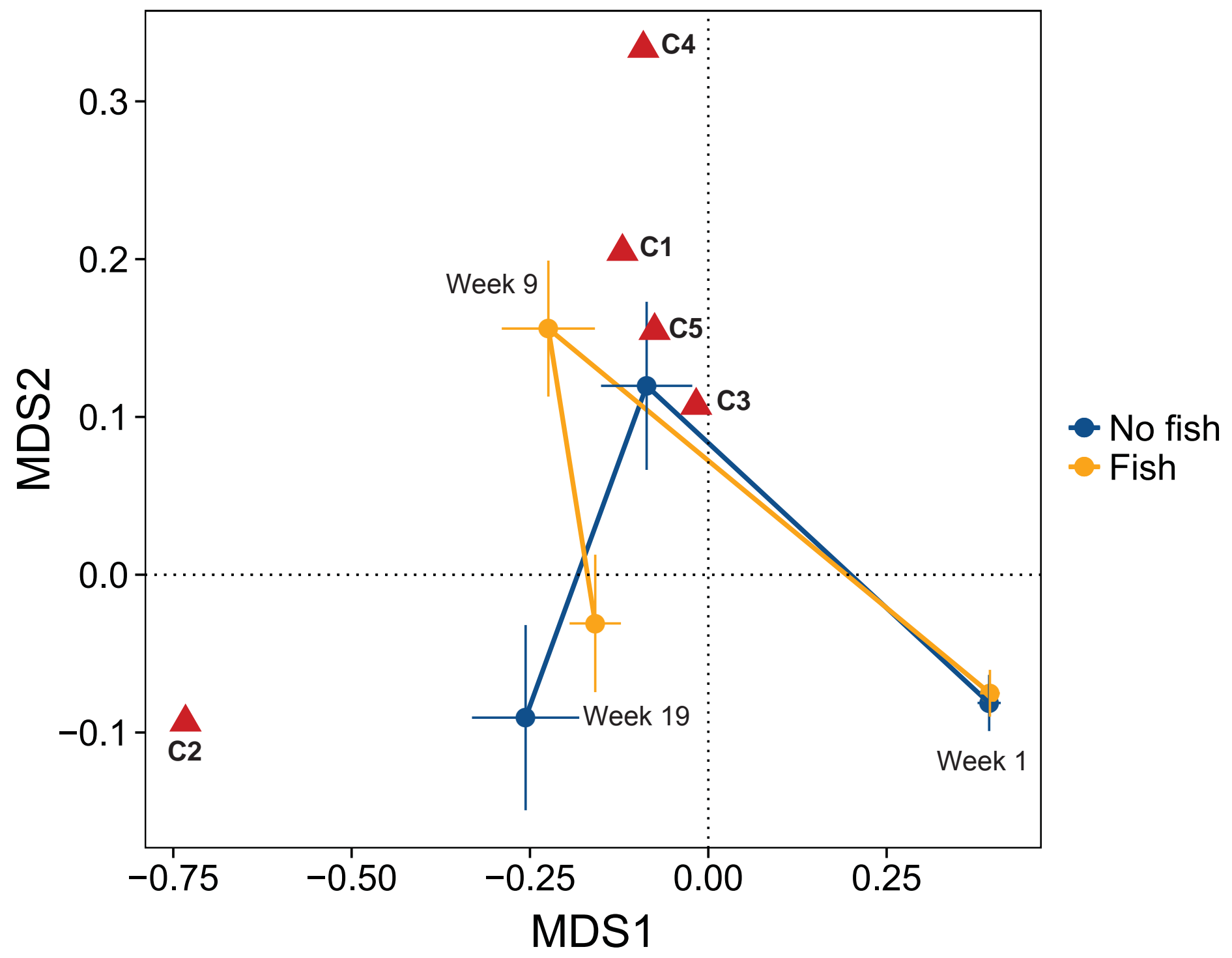

Fig. A5: Principle Coordinates Analysis of the five PARAFAC components. PCoA was computed using the absolute values of the five PARAFAC components from weeks 1, 9, and 19. Values were not normalized by DOC concentration prior to analysis. Scores of the five PARAFAC components were scaled by a factor of 5 prior to plotting and are shown with red triangles. 


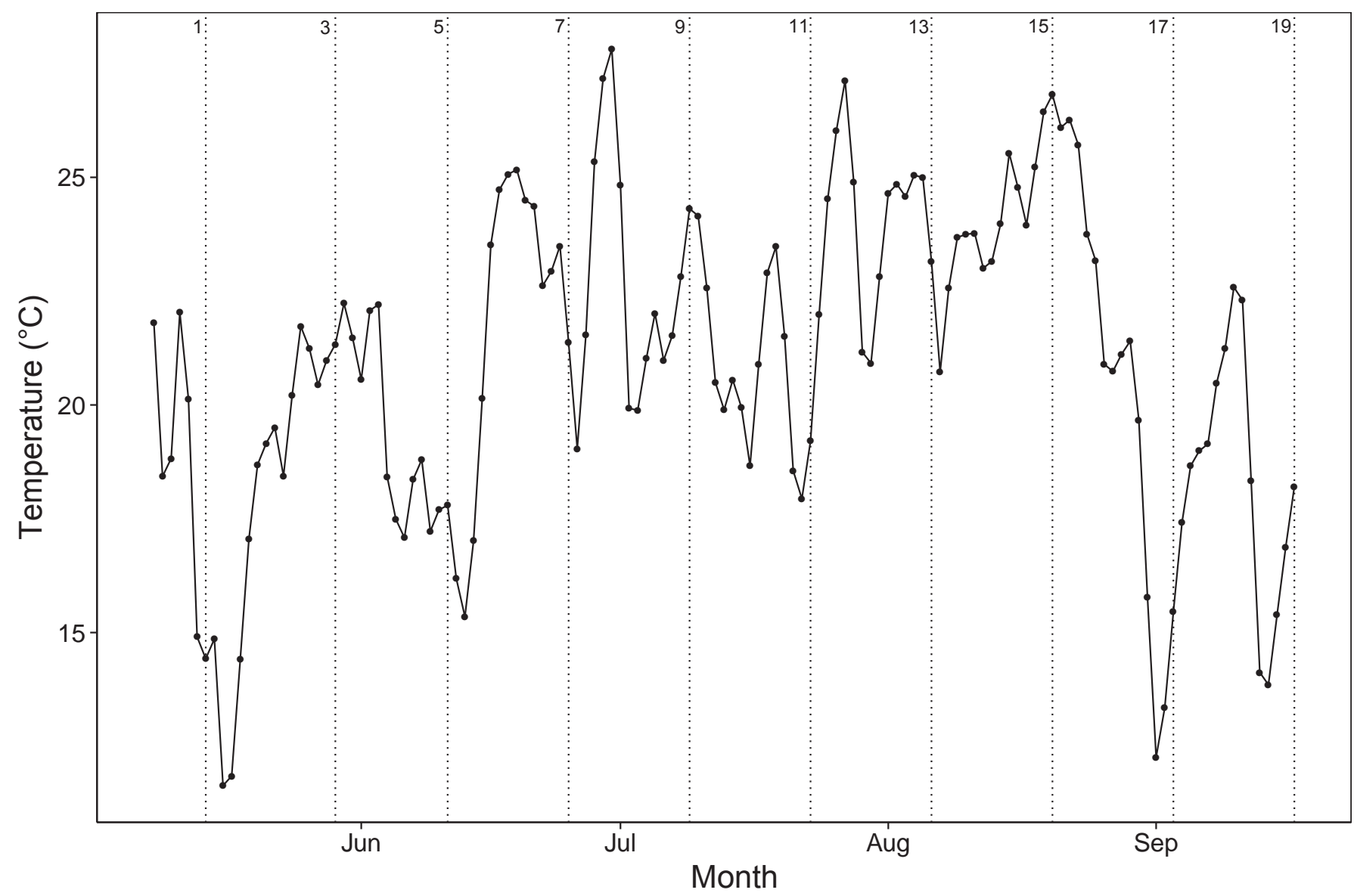

Fig. A6: Water temperature in the mesocosms. Temperature was measured with data loggers in nine mesocosms in 15 minute intervals. Values are daily averages of the nine tanks. Vertical dotted lines mark the ten sampling dates (Week 1 to 19). 